\title{
AKTIVIRANJE GOSPODARJENJA V ZASEBNIH GOZDOVIH S POSLOVNIM SODELOVANJEM MED ZASEBNIMI LASTNIKI GOZDOV IN PONUDNIKI GOZDARSKIH STORITEV: ŠTUDIJ PRIMERA REVIR VODICE ACTIVATING PRIVATE FOREST MANAGEMENT THROUGH BUSINESS COOPERATION BETWEEN PRIVATE FOREST OWNERS AND FOREST SERVICE PROVIDERS: A CASE STUDY OF THE VODICE FOREST DISTRICT
}

\author{
Nina IVETA ${ }^{1}$, Špela PEZDEVŠEK MALOVRH ${ }^{2}$ \\ (1) Zavod za gozdove Slovenije, nina.iveta@zgs.si \\ (2) Univerza v Ljubljani, Biotehniška fakulteta, Oddelek za gozdarstvo in obnovljive gozdne vire, spela.pezdevsek.malovrh@bf.uni-lj.si
}

\begin{abstract}
IZVLEČEK
V prispevku smo preverjali možnost aktiviranja gospodarjenja v zasebnih gozdovih s pomočjo poslovnega povezovanja znotraj poslovnih modelov »zakup gozda« in »upravljanje gozda« med zasebnimi lastniki gozdov in ponudniki gozdarskih storitev. $\mathrm{S}$ pomočjo anketiranja zasebnih lastnikov gozda $(n=205)$ in ponudnikov gozdarskih storitev $(n=14)$ smo ugotovili, da je pripravljenost za poslovno sodelovanje $\mathrm{v}$ obeh predlaganih poslovnih modelih večja pri ponudnikih gozdarskih storitev, kot pa je pri zasebnih lastnikih gozdov. Nadalje smo ugotovili, da je poslovno sodelovanje znotraj predlaganih poslovnih modelov uresničljivo, saj je stopnja sodelovanja zasebnih lastnikov gozdov s ponudniki gozdarskih storitev v 10-letnem obdobju zadovoljiva, hkrati pa so se predlagani pogoji, ki urejajo poslovno razmerje in temeljne obveznosti pogodbenih strank, izkazali za primerne za oba poslovna partnerja. Za začetek vzpostavitve poslovnega sodelovanja je treba najprej poskrbeti za promocijo poslovnega povezovanja in sodelovanja na lokalnem nivoju ter vzpostaviti poslovne odnose med potencialnimi partnerji.
\end{abstract}

Ključne besede: zasebni gozdovi, gospodarjenje, poslovno sodelovanje zasebnih lastnikov gozdov, ponudniki gozdarskih storitev, poslovni modeli, zakup gozda, upravljanje gozda

\begin{abstract}
We investigated the possibility of activating private forest management through business cooperation within "forest lease" and "forest management" business models between private forest owners (PFOs) and forest service providers. By surveying PFOs ( $\mathrm{n}=205)$ and forest service providers $(\mathrm{n}=14)$, we found that the willingness to engage in business cooperation in both proposed business models is higher among forest service providers than PFOs. In addition, we found that business cooperation within the proposed business models is feasible because the level of cooperation of PFOs with forest service providers over a 10 -year period is satisfactory, and the proposed terms and conditions governing the business relationship and basic contract obligations of the contracting parties have proven to be appropriate for both business partners. In order to establish business cooperation, it is first necessary to promote business cooperation at the local level and to establish business relations between potential partners.
\end{abstract}

Key words: private forests, management, business cooperation of private forest owners, forest service providers, business models, forest lease, forest management

\section{UVOD}

\section{INTRODUCTION}

Slovenija je ena izmed najbolj gozdnatih držav Evrope in je po podatkih Zavoda za gozdove Slovenije (ZGS) prekrita z 58,1 \% gozdnih površin (Poročilo ..., 2019). Večina slovenskih gozdov (76 \%) je v zasebni lasti, državnih gozdov je $21 \%, 3 \%$ gozdov pa je v lasti lokalne skupnosti (Poročilo ..., 2019). Zaradi prevladujočega deleža zasebnih gozdov tako v Sloveniji kot tudi v Evropi, ki bistveno prispevajo k trajnostnemu razvo- ju ekosistemov ter oskrbi trgov z gozdno-lesnimi sortimenti (GLS), ima preučevanje gospodarjenja s temi gozdovi velik pomen (Fabra-Crespo in Rojas-Briales, 2015; Poje in sod., 2016; Pezdevšek Malovrh in sod., 2017; Weiss in sod., 2019a; Weiss in sod., 2019b).

Za zasebne gozdove v Sloveniji je značilna majhna zasebna posest, ki je v lasti velikega števila lastnikov (okoli 314.000), oziroma okoli 489.000, vključno s solastniki. Povprečna gozdna posest v povprečju meri le okoli 2,5 ha (Poročilo ..., 2019) in je razdrobljena na 
posamezne prostorsko ločene parcele (Breznikar in sod., 2017). Realizacija rednega možnega poseka v zasebnih gozdovih ne dosega načrtovanega obsega in $\mathrm{v}$ povprečju dosega le $65 \%$ možnega poseka, določenega v gozdnogospodarskih načrtih gozdnogospodarskih enot (Poročilo ..., 2019).

Beach in sod. (2005) ter Poje in sod. (2016) so ugotovili, da na gospodarjenje $\mathrm{z}$ zasebnimi gozdovi vplivajo številni dejavniki, ki so razdeljeni v naslednje kategorije, in sicer: tržni dejavniki, politični dejavniki, socio-demografske značilnosti zasebnih lastnikov gozda ter posestni in naravni dejavniki. Poleg tega raziskave ugotavljajo, da se značilnosti zasebnih lastnikov gozdov spreminjajo, vedno več je tako imenovanih mestnih lastnikov, ženskih lastnic in zasebnih lastnikov, ki nimajo gozdarskega znanja (Karppinen, 2012; Côté in sod., 2017; Umaerus in sod., 2019). Nove skupine zasebnih lastnikov gozdov nimajo tradicionalnih ciljev in motivov za lastništvo gozda in gospodarjenje z njim (Matilainen in sod., 2019; Weiss in sod., 2019a). To je izziv tako za sektor gozdarskih storitev, predvsem za združenja zasebnih lastnikov gozdov in podjetja (ponudnike gozdarskih storitev), kot tudi za sektor gozdarstva na splošno, saj ti zasebni lastniki gozdov nimajo potrebnega znanja in izkušenj za delo v gozdu. Posledično lahko pričakujejo vedno večjo potrebo po bolj celostnih in kompleksnih storitvah predvsem $s$ strani oblik povezovanja zasebnih lastnikov gozdov in pa ponudnikov gozdarskih storitev (Andersson in Keskitalo, 2019; Laakkonen in sod., 2019; Andersson in sod., 2020).

Raziskave tako doma kot v tujini že dolgo opozarjajo, da je za aktiviranje gospodarjenja treba majhno in razdrobljeno zasebno gozdno posest združevati in zasebne lastnike gozdov povezovati v različne organizacijske oblike (Krajčič in Mori , 2006; Mori in sod., 2006; Glück in sod., 2010; Pezdevšek Malovrh, 2010; Pezdevšek Malovrh in sod., 2011; Mizaraitė in Mizaras, 2014; Põllumäe in sod., 2014; Pezdevšek Malovrh in Laktić, 2017; Černač in Pezdevšek Malovrh, 2020), hkrati pa zagotoviti začetno finančno podporo za delovanje oblik povezovanja ter ponuditi storitve, ki bodo pritegnile zasebne lastnike gozdov k sodelovanju (Hansmann in sod., 2016).

Tako v Sloveniji kot v Evropi zasebni lastniki gozdov sodelujejo $\mathrm{v}$ različnih organizacijskih oblikah povezovanja. Ne glede na pozitivne učinke povezovanja, ki so dokazani v številnih raziskavah (Pezdevšek Malovrh, 2010; Mori, 2012; Leban, 2014; Mizaraitė in Mizaras, 2014; Hrib in sod., 2018), se oblike povezovanja spoprijemajo s prenizkim številom članov, omejenimi finančnimi sredstvi in neučinkovitostjo delova- nja (Krajčič in Mori, 2006; Weiss in sod., 2012a; Weiss in sod., 2012b; Fabra-Crespo in Rojas-Briales, 2015; Šálka in sod., 2016; Hrib in sod., 2018). Zato ne preseneča, da nekatere oblike razmišljajo v smeri profesionalizacije in ponujanja novih storitev za člane (Krajčič in Mori, 2006; Erlandsson, 2013; Kronholm, 2016), povezovanja z drugimi deležniki vzdolž gozdno-lesne verige (Hansmann in sod., 2016; Górriz-Mifsud in sod., 2019; Laakkonen in sod., 2019) ali v smeri preoblikovanja oziroma vzpostavitve novih poslovnih modelov sodelovanja (Erlandsson, 2013; Andersson in Keskitalo, 2019; Laakkonen in sod., 2019; Andersson in sod., 2020).

Oblike povezovanja so na gozdarsko-politični ravni v Sloveniji sprejete kot ustrezen ukrep za rešitev problemov neučinkovitega gospodarjenja z zasebnimi gozdovi (Šinko, 2012). Resolucija o Nacionalnem gozdnem programu (Resolucija o nacionalnem gozdnem programu, 2007) navaja nepovezanost lastnikov gozdov pri izvedbi del v gozdovih in prodaji lesa kot dejavnik, ki zmanjšuje gospodarske učinke gozdov in kot ukrep predvideva povezovanje lastnikov gozdov, ter zagotavljanje večje realizacije del s strani poklicnih izvajalcev, ki delajo na tehnološko sodoben in varen način. Poročilo o uresničevanju Nacionalnega gozdnega programa do leta 2014 ugotavlja, da obseg in vsebina strokovnega, načrtnega in dejavnejšega spodbujanja lastnikov gozdov za gospodarjenje in poslovno povezovanje ne dosegata želenih rezultatov, saj tovrstnega povezovanja praktično ni (Poročilo o izvajanju Nacionalnega gozdnega programa do 2014, 2016). Zato se v Operativnem programu za izvajanje Nacionalnega gozdnega programa 2017-2021 predvideva v okviru 2. prioritete »Zagotavljanje trajnostnih donosov gozdov in uveljavitve vseh njihovih funkcij«, ukrep, katerega namen je povečati delež realiziranega možnega poseka in izvedbo negovalnih del predvsem $\mathrm{v}$ zasebnih gozdovih v skladu z veljavnimi načrti za gospodarjenje $\mathrm{z}$ gozdovi. Pri tem navajajo, da bi bil večji premik v smeri poslovnega povezovanja lahko dosežen s pomočjo podpor za vzpostavitev skupin in organizacij proizvajalcev GLS, oziroma povezovanje zasebnih lastnikov gozdov za skupno prodajo lesa in (morebitno) skupno organiziranje gozdne proizvodnje (Operativni program za izvajanje Nacionalnega gozdnega programa 2017-2021, 2017). Če želimo doseči premik na tem področju, pa ne smemo pozabiti na dejstva, in sicer: a) da se trenutne lokalne oblike povezovanja zasebnih lastnikov gozdov posvečajo predvsem informiranju in izobraževanju svojih članov in organiziranju ekskurzij ter dogodkov; b) da so primeri dobrih praks poslovnega povezovanja zasebnih lastnikov gozdov zelo redki; in c) da so 
zasebni lastniki gozdov v Sloveniji vedno bolj heterogeni (Pezdevšek Malovrh in sod., 2015; Kumer in Potočnik Slavič, 2016). Dejstva nakazujejo na potrebo po visoko kakovostnih tako imenovanih »all-inclusive« storitvah gospodarjenja z gozdovi za zasebne lastnike gozdov s strani različnih deležnikov ter po vzpostavitvi novih poslovnih modelov sodelovanja med zasebnimi lastniki gozdov in drugimi deležniki. Pred umestitvijo takšnih poslovnih modelov v primerno organizacijsko, politično in institucionalno okolje je treba raziskati pripravljenost različnih deležnikov za sodelovanje in njihove ocene o primernosti različnih modelov poslovnega sodelovanja.

$\mathrm{V}$ naši raziskavi želimo predstaviti dva potencialna modela poslovnega sodelovanja med zasebnimi lastniki gozdov in ponudniki gozdarskih storitev, in sicer zakup gozdov in upravljanje gozdov, ter ugotoviti: a) ali so zasebni lastniki gozdov in ponudniki gozdarskih storitev v preteklosti že sodelovali in na kakšen način, b) ali so zasebni lastniki gozdov in ponudniki gozdarskih storitev pripravljeni za poslovno sodelovanje v predlaganih poslovnih modelih, c) kako primerni se zdijo zasebnim lastnikom gozdov in ponudnikom gozdarskih storitev predlagani pogodbeni pogoji, in d) ali so zasebni lastniki gozdov pripravljeni za povezovanje v organizacijske oblike na lokalnem nivoju in nadaljnje poslovno sodelovanje s ponudniki gozdarskih storitev oziroma ali so jih le ti pripravljeni pred poslovnim sodelovanjem povezovati.

\section{OBJEKT RAZISKAVE}

\section{RESEARCH OBJECT}

Objekt naše raziskave je revir Vodice, ki je po posestni in lastniški strukturi zasebnih gozdov ter realizaciji možnega poseka primerljiv s stanjem na ravni Slovenije. Leži v gozdnogospodarski enoti Medvode in organizacijsko spada v Območno enoto Ljubljana. Zavzema 3.249,49 ha gozdov. Gozdnatost je 50,1 \% (Baza ..., 2020). V revirju Vodice prevladujejo zasebni gozdovi, ki obsegajo $2.832,81$ ha $(87,18 \%$ vseh gozdov) in so v lasti 1.492 lastnikov, oziroma 4.159 vključno s solastniki. Povprečna velikost gozdne parcele je 0,45 ha, gozdne posesti pa 1,90 ha (Baza ..., 2020). Zasebna gozdna posest $\mathrm{v}$ revirju Vodice je zelo razdrobljena. Lastniki gozdov imajo povprečno gozdno posest $v$ treh kompleksih.

Možni posek za obdobje od 2009 do 2019 za revir Vodice je znašal v zasebnih gozdovih $175.328 \mathrm{~m}^{3}$ (110.190 $\mathrm{m}^{3}$ za iglavce in $65.138 \mathrm{~m}^{3}$ za listavce), kar pomeni v povprečju $17.532,80 \mathrm{~m}^{3}$ na leto. Po evidenci ZGS je bilo od leta 2007 do leta 2014, ko je revir Vodice močno poškodoval žledolom, posekano v zaseb- nih gozdovih $63.754 \mathrm{~m}^{3}$ lesa, kar pomeni v povprečju $9.107,70 \mathrm{~m}^{3}$ lesa na leto. Iz tega sledi, da je realizacija možnega poseka (redna sečnja) od leta 2010 do leta 2014 v revirju Vodice znašala le 51,9 \%. Zaradi žledoloma in posledično napada podlubnikov se je realizacija povečala, saj je bilo od leta 2014 do danes posekanih $94.948 \mathrm{~m}^{3}$ zaradi žledoloma ter $28.317 \mathrm{~m}^{3}$ lesa zaradi podlubnikov.

$\mathrm{V}$ gozdnogospodarskem načrtu gozdnogospodarske enote Medvode je bilo za obdobje od 2009 do 2019 v revirju Vodice načrtovanih 103,53 ha gojitvenih in varstvenih del, kar pomeni 10,35 ha na leto. Po evidencah ZGS realizacija opravljanja gojitvenih in varstvenih del v revirju Vodice znaša 94,3 \%. Med opravljenimi deli prevladuje obnova gozda, in sicer sadnja ter nujno izvajanje obžetev na sajenih površinah (od 3 do 6 let, odvisno od rastišča), sledi nega letvenjaka, gošče in mladja. Umetna obnova je v ravninskem predelu revirja Vodice nujna in potrebna, saj je naravno pomlajevanje zaradi zapleveljenosti z borovnico (Vaccinium myrtillus) in orlovo praprotjo (Pteridium aquilinum) močno oteženo.

3 MOŽNI OBLIKI POSLOVNEGA SODELOVANJA MED ZASEBNIMI LASTNIKI GOZDOV IN PONUDNIKI GOZDARSKIH STORITEV

3 POSSIBLE FORMS OF BUSINESS COOPERATION BETWEEN PRIVATE FOREST OWNERS AND FOREST SERVICE PROVIDERS

$\mathrm{V}$ našo raziskavo smo za aktiviranje gospodarjenja z zasebnimi gozdovi vključili ponudnike gozdarskih storitev kot deležnike, ki bi bili glavni pobudniki poslovnega povezovanja in sodelovanja, ne glede na pravno-formalno obliko. Med njimi in zasebnimi lastniki gozdov obravnavamo dve obliki poslovnih razmerij, in sicer zakup gozdov in upravljanje gozdov (Kurttila in sod., 2016), ter preverjamo njuno uresničljivost na primeru revirja Vodice. Zaradi raznolikosti poslovnih razmerij poudarjamo, da je pri izbiri le teh treba upoštevati dejanske posestne in lastninske razmere, gozdnogospodarske razmere ter socio-ekonomske značilnosti zasebnih lastnikov gozdov.

Zakupno razmerje in razmerje o upravljanju gozdov sta v osnovnih izhodiščih podobna, saj se dolgoročna pogodba sklene med zasebnim lastnikom gozda in ponudnikom gozdarskih storitev, predmet pogodbe pa so zasebni gozdovi. Razlikujeta pa se v ekonomskih razmerah, odločanju o rabi in uživanju predmeta pogodbe ter dinamiki gospodarjenja $\mathrm{z}$ gozdom. $\mathrm{V}$ nadaljevanju prikazujemo značilnosti posamezne oblike poslovnega razmerja. 


\subsection{Zakup gozdov}

\subsection{Forest leasing}

Zakup gozdov je civilno pravno, dolgoročno poslovno razmerje, katerega splošne zakonske norme določata Obligacijski zakonik (Ur. l. RS. 97/2007) ter Zakon o kmetijskih zemljiščih (Ur. l. RS. 71/2011). Pogodbo o zakupu gozdov skleneta ponudnik gozdarskih storitev kot zakupnik in zasebni lastnik gozda kot zakupodajalec. Predmet zakupne pogodbe je zasebni gozd. Na podlagi zakupne pogodbe se zakupodajalec zavezuje, da bo zakupniku izročil predmet pogodbe $\mathrm{v}$ rabo ( $\mathrm{v}$ skladu z zakonom in predpisi, ki urejajo gozdove, varstvo okolja in ohranjanje narave), ki obsega tudi uživanje predmeta pogodbe (pobiranje plodov), pri tem pa se zakupnik zavezuje, da mu bo za to plačeval v pogodbi določeno zakupnino. Zakonodaja določa, da se zakupna pogodba sklene za dobo, ki ustreza namenu uporabe, pri čemer le ta ne sme biti krajša od 10 let, če se zemljišče uporablja za druge namene, ne določa pa dolžine trajanja zakupa. Kljub temu, da zakonodaja napeljuje na daljša zakupna razmerja, je določanje dobe zakupa gozdov stvar dogovora med zakupnikom in zakupodajalcem. Zakupnik se obvezuje, da bo gospodaril z gozdom v skladu z zakupno pogodbo, pri čemer prevzame odgovornost za izvedbo vseh pogodbeno dogovorjenih gozdnogospodarskih del (npr.: sečnja in spravilo lesa, prevoz GLS, prodaja GLS, opravljanje gojitvenih in varstvenih del, graditev in vzdrževanje gozdne infrastrukture, pridobivanje in prodaja drugih gozdnih dobrin itd.) ter poslovodenje (npr.: vodenje prihodkov in stroškov, sodelovanje z revirnim gozdarjem itd.). Zakonodaja določa tudi odgovornost zakupnika za morebitno škodo $\mathrm{v}$ primeru rabe zakupljenega predmeta $\mathrm{v}$ nasprotju s pogodbo ali $\mathrm{z}$ njenim namenom, ne glede na to, ali jo je uporabljal sam ali nekdo, ki je delal po njegovem naročilu, podzakupnik ali kdo drug, ki mu je on omogočil rabo predmeta, kar pomeni, da s pogodbo prevzema vso odgovornost za obstoj in razvoj gozda.

Pri zakupu gozdov pa nikakor ne gre za klasično zakupno razmerje, kot ugotavljajo Winkler (1998) in Kurttila in sod. (2016), saj: a) zavezuje zakupnika gozdov gospodariti $\mathrm{z}$ gozdom $\mathrm{v}$ skladu $\mathrm{z}$ gozdarsko zakonodajo ter veljavnimi gozdnogospodarskimi in gozdnogojitvenimi načrti, pri čemer se sam odloča o dinamiki opravljanja del; b) zakupnine ni mogoče določiti v fiksnem znesku za celotno obdobje, temveč se le ta določi enkrat letno glede na proizvodne razmere, plačuje pa se lahko enkrat letno/polletno ali pa $v$ mesečnih obrokih; c) se zakupno razmerje sklepa za daljše, vendar časovno omejeno obdobje, ki sledi desetletnemu obdobju veljavnosti gozdnogospodarskih načrtov (npr. za 10 ali 20 letno obdobje); in d) je pre- kinitev pogodbe mogoča le s soglasjem obeh poslovnih partnerjev, če je zakupnik gozd uporabljal kot dober gospodar; zakupnik lahko prekine pogodbo predčasno brez razloga le v zameno za plačilo (npr. enoletno zakupnino); zakupodajalec pa jo lahko prekine v primeru po pogodbi nasprotne rabe ali neplačane zakupnine - $\mathrm{v}$ tem primeru lahko zakupodajalec brez predhodnega obvestila odpove to pogodbo brez odpovednega roka in proti plačila.

\subsection{Upravljanje gozdov}

\subsection{Forest management}

Upravljanje gozdov je civilno pravno, dolgoročno poslovno razmerje, katerega splošne zakonske norme le delno določa Obligacijski zakonik (Ur. l. RS. 97/2007). Pogodbo o upravljanju skleneta ponudnik gozdarskih storitev kot upravitelj in zasebni lastnik gozda. Predmet upravljanja je zasebni gozd. Na podlagi pogodbe o upravljanju se zasebni lastnik gozda zavezuje, da bo upravitelju izročil predmet pogodbe $v$ upravljanje (v skladu z zakonom in predpisi, ki urejajo gozdove, varstvo okolja in ohranjanje narave). Pogodba o upravljanju se sklene za dobo, ki ustreza namenu uporabe in je zelo pogosto sklenjena za nedoločen čas. Upravitelj se zavezuje, da bo upravljal/gospodaril z gozdom v skladu s pogodbo o upravljanju, pri čemer prevzame odgovornost za izvedbo vseh pogodbeno dogovorjenih gozdnogospodarskih del (npr:: opravljanje vseh ali le posameznih gozdnogospodarskih del oziroma iskanje izvajalcev del, prodaja GLS, pridobivanje in prodaja drugih gozdnih dobrin, sodelovanje $\mathrm{z}$ revirnim gozdarjem itd.). Odločitev pri gospodarjenju z gozdom ne sprejema upravitelj, temveč zasebni lastnik gozda, pri čemer v sodelovanju z ZGS sam odloča o ciljih gospodarjenja ter dinamiki izvajanja ukrepov za uresničevanje ciljev. Upravitelj zastopa zasebnega lastnika gozda in je obvezan vsa gozdnogospodarska dela opravljati oziroma oddajati v opravljanje v skladu z gozdarsko zakonodajo ter veljavnimi gozdnogospodarskimi in gozdnogojitvenimi načrti. Upravitelj ima pomembno vlogo tudi pri nadzoru nad izvedbo različnih gozdnogospodarskih del, saj se v imenu zasebnega lastnika gozda dogovarja $\mathrm{z}$ različnimi izvajalci del oziroma dela opravlja sam. V primeru, da je upravitelj hkrati tudi izvajalec del, je pomembno, da ne pride do nasprotja interesov. S pogodbo se lastnik gozda zavezuje, da bo upravitelju za upravljanje gozda plačeval v pogodbi določeno nadomestilo. 0 višini nadomestila se dogovorita pogodbena partnerja, le ta pa je odvisna od višine čistega donosa, izkazanega v letnem poročilu o poslovanju, ki temelji na prikazu doseganja ciljev gospodarjenja in poslovnem izidu. Letno poročilo o po- 
slovanju pripravi upravitelj. Višina nadomestila se določi enkrat letno, vključuje fiksni in variabilni del glede na kvaliteto opravljenih del in doseženih cen za GLS na trgu, plačuje pa se lahko enkrat letno/polletno ali pa v mesečnih obrokih. Prekinitev pogodbe je mogoča le s soglasjem obeh poslovnih partnerjev, če upravitelj gozd upravlja kot dober gospodar; zasebni lastnik gozda lahko kadarkoli predčasno prekine pogodbo brez razloga $\mathrm{z}$ odpovednim rokom in brez finančnega protiplačila oziroma jo v primeru po pogodbi nasprotnega upravljanja lahko prekine brez predhodnega obvestila in brez odpovednega roka.

\section{MATERIALI IN METODE}

\section{MATERIALS AND METHODS}

Podatke o trenutnem gospodarjenju z gozdovi, pripravljenosti za poslovno sodelovanje ter primernosti pogodbenih pogojih za uresničljivost predlaganih poslovnih modelov smo pridobili s pomočjo dveh ločenih anketnih vprašalnikov, namenjenih zasebnim lastnikom gozdov ter ponudnikom gozdarskih storitev na območju revirja Vodice (Iveta, 2017). Anketni vprašalnik je bil pripravljen v okviru projekta »Family forest owners' opinion on potential forest leasing service« in prilagojen slovenskim razmeram na osnovi študije »Forest leasing service potential in Slovenia - a feasibility study« (Kurttila in sod., 2016). Anketi sta bili anonimni, zato individualnih podatkov o anketirancih ne navajamo. Anonimnost podatkov smo zagotovili s šifriranjem anket med raziskavo.

\subsection{Anketiranje zasebnih lastnikov gozdov}

\subsection{Survey of PFOs}

Populacijo za izvedbo anketiranja je predstavljalo vseh 1.492 zasebnih lastnikov gozdov v revirju Vodice, ki smo jih identificirali na podlagi podatkovne zbirke ZGS, tako imenovani »Indeks gozdnih posestnikov«. Velikost vzorca $(n=306)$ smo določili s pomočjo Sample size calculator-ja (Calculator, 2017), pri čimer smo upoštevali 5-odstotni interval zaupanja. V vzorec smo nato naključno izbrali 306 zasebnih lastnikov gozdov iz revirja Vodice. Anketiranje smo opravili prek splethe ankete $1 \mathrm{KA}$, ki smo jo po elektronski pošti poslali zasebnim lastnikom gozdov, po predhodnem telefonskem dogovoru z njimi. Anketiranje je potekalo v mesecu septembru in oktobru leta 2017. Anketo je izpolnilo 205 oziroma 67,0 \% zasebnih lastnikov gozdov, zajetih v vzorec. Zasebni lastniki gozdov, ki so sodelovanje v anketi zavrnili, so imeli posest manjšo od 0,1 ha, pri čemer so kot najpogostejši razlog nepripravljenosti za sodelovanje navedli nezainteresiranost za gospodarjenje z gozdom, starost ter pomanjkanje časa.
Anketni vprašalnik za zasebne lastnike gozdov je bil razdeljen na dve poglavji, in sicer na poglavje A osnovni podatki o anketirancu in njegovem gozdu ter gospodarjenju z gozdom; ter poglavje B - poslovno sodelovanje. V poglavju A smo pridobili podatke, povezane s socio-demografskimi značilnostmi zasebnih lastnikov gozdov, posestnimi in lastniškimi razmerji ter gospodarjenjem z gozdovi. V poglavju B smo pridobili podatke o preteklem poslovnem sodelovanju s ponudniki gozdarskih storitev, lastnikovi pripravljenosti za poslovno sodelovanje s ponudniki gozdarskih storitev ter pogojih, pod katerimi bi bili pripravljeni za poslovno sodelovanje s ponudniki gozdarskih storitev.

\subsection{Anketiranje ponudnikov gozdarskih storitev}

\subsection{Survey of forest service providers}

Osnovne podatke o ponudnikih gozdarskih storitev $\mathrm{v}$ revirju Vodice smo dobili s pomočjo ankete, opravljene med zasebnimi lastniki gozdov, $v$ kateri so le ti povedali, s katerim ponudnikom gozdarskih storitev so $\mathrm{v}$ preteklih desetih letih že sodelovali pri gospodarjenju z gozdom. Na podlagi teh informacij smo pripravili bazo vseh ponudnikov gozdarskih storitev v revirju Vodice ( $n=23$ ). Ker je bilo ponudnikov gozdarskih storitev malo, smo se v tem primeru odločili za popoln vzorec. Zaradi zaprtja podjetij treh identificiranih ponudnikov smo v vzorec vključili 20 ponudnikov gozdarskih storitev. Anketiranje je potekalo prek spletne ankete 1KA, ki smo jo po elektronski pošti poslali vsem ponudnikom gozdarskih storitev, po predhodnem telefonskem dogovoru z njimi. Anketiranje smo izvajali v mesecu novembru leta 2017. Na anketni vprašalnik je odgovorilo 14 ponudnikov gozdarskih storitev, kar pomeni, da smo dosegli 70-odstotno realizacijo zastavljenega cilj

Anketni vprašalnik za ponudnike gozdarskih storitev je bil razdeljen na dve poglavji. V poglavju A smo pridobili osnovne podatke o podjetju in njegovem delovanju, v poglavju B pa podatke o njihovem preteklem poslovnem sodelovanju z zasebnimi lastniki gozdov, njihovi pripravljenosti za poslovno sodelovanje ter pogoji, pod katerimi bi bili pripravljeni za poslovno sodelovanje ter povezovanje zasebnih lastnikov gozda.

\subsection{Metode za obdelavo anketnih podatkov}

\subsection{Methods for survey data analysis}

Zbrani podatki obeh anketnih vprašalnikov sestavljajo dve osnovni podatkovni zbirki, na podlagi katerih smo opravili analize. Zbirko podatkov iz obeh anket smo pripravili v programu Excel, kjer smo s frekvenčnimi analizami in logičnimi kontrolami preverili vnos podatkov. Sledila je statistična analiza podatkovnih zbirk v programskem okolju SPSS 21.0 s pomočjo sta- 
tističnih metod, pri čemer smo za statistično značilne upoštevali vrednosti $p<0,05$. Osnovne analize smo opravili s pomočjo opisnih statistik, frekvenčnih porazdelitev posameznih znakov in s križnimi tabelami. Numerične spremenljivke smo opisali z ustreznimi srednjimi vrednostmi (aritmetično sredino). Opisne spremenljivke smo preoblikovali v kategorične in jih opisali s frekvencami (Field, 2018).

\section{REZULTATI IN RAZPRAVA}

\section{RESULTS AND DISSCUSSION}

\subsection{Osnovne značilnosti anketirancev}

5.1 Basic characteristics of interviewees

5.1.1 Osnovne značilnosti zasebnih lastnikov gozdov in njihovih gozdnih posesti

5.1.1 Basic characteristics of PFOs and their forest properties

$\mathrm{V}$ anketi je sodelovalo 205 zasebnih lastnikov gozda, med katerimi je bilo 66,0 \% moških in 34,0 \% žensk. Povprečna starost anketiranih zasebnih lastnikov gozdov je bila 58 let (ekstrema sta pri 24 in 96 letih), kar se sklada s starostno strukturo povprečnega slovenskega zasebnega lastnika gozda (Breznikar in sod., 2017; Kumer, 2017). Izobrazbena struktura anketiranih zasebnih lastnikov gozda je dobra, saj jih ima 61,5 \% dokončano srednjo šolo ali višjo stopnjo izobrazbe. Dobra izobrazbena struktura ne preseneča, saj poklicna struktura anketiranih zasebnih lastnikov gozdov kaže, da v revirju Vodice prevladujejo nekmetje $(94,1$ $\%)$, ki so v 53,2 \% delovno aktivni. Socio-demografske značilnosti anketiranih zasebnih lastnikov gozdov nakazujejo, da prevladujejo delovno aktivni nekmetje, zato lahko pričakujemo, da se bo zaradi njihove starosti in socio-ekonomskega profila povečala potreba po najemanju storitev povezanih z gospodarjenjem z gozdovi.

Povprečna velikost zasebne gozdne posesti anketiranih zasebnih lastnikov je 2,59 ha (ekstrema sta pri 0,01 in 40,00 ha), kar je enako slovenskemu povprečju (Poročilo ..., 2019). Slaba polovica (49,7 \%) anketiranih zasebnih lastnikov gozdov ima posesti manjše od 1 ha, sledijo zasebni lastniki, ki imajo posest veliko od 1 do 5 ha $(32,2 \%)$, ter tisti, ki imajo posest večjo od 5 ha - le teh je v vzorcu 18,1 \%. Zasebni lastniki gozdov imajo povprečno gozdno posest $\mathrm{v}$ treh kompleksih (ekstrem 10 kompleksov), kar je enako slovenskemu povprečju (Medved, 2000; Pezdevšek Malovrh, 2010). $\mathrm{V}$ enem kompleksu jih ima posest 32,1 \%,v dveh kompleksih 29,3 \%,v treh kompleksih $11,7 \%$, ter na več kot štirih kompleksih 26,4 \% anketiranih zasebnih lastnikov gozdov. Do podobnih rezultatov je prišel tudi
Kumer (2017), ki je na ravni Slovenije ugotovil, da ima $48,6 \%$ lastnikov majhnih gozdnih posesti (do 5 ha) svojo gozdno posest pretežno v enem do dveh kompleksih. V povprečju imajo anketirani zasebni lastniki gozdov gozdno posest oddaljeno od svojega prebivališča $15,1 \mathrm{~km}$, pri čemer skoraj polovica anketiranih $(49,8$ \%) živi blizu svojega gozda (oddaljenost od gozda je pod $1 \mathrm{~km}$ ). Dve tretjini anketiranih zasebnih lastnikov gozda $(66,3 \%)$ si tega ne deli z nikomer, tretjina $(33,7$ $\%)$ pa ima gozdove v solastništvu. Med slednjimi prevladujejo tisti, ki imajo gozdne posesti v solastništvu s sorodniki $(60,9 \%)$, sledijo zasebni lastniki gozdov, ki imajo gozd v solastništvu z zakoncem (34,8 \%), ter tisti, ki imajo gozd v solastništvu s tretjimi osebami $(4,3$ \%). Prevladujoča oblika lastništva »lastnik sam« med anketiranimi lastniki gozdov govori v prid poslovnemu sodelovanju, saj po ugotovitvah Pezdevšek Malovrh in Laktić (2017) večjo pripravljenost za poslovno povezovanje izkazujejo lastniki, ki so brez solastnikov, kar je povezano z večjo samostojnostjo pri poslovnem odločanju.

\subsubsection{Osnovne značilnosti ponudnikov gozdarskih storitev \\ 5.1.2 Basic characteristics of forest service provid- ers}

Med anketiranimi ponudniki gozdarskih storitev je $57,1 \%$ samostojnih podjetnikov in $42,9 \%$ gospodarskih družb z omejeno odgovornostjo. Večina ponudnikov gozdarskih storitev $(85,7 \%)$ ima sedež svojega podjetja zunaj revirja Vodice, $14,3 \%$ pa v revirju. $\mathrm{V}$ povprečju imajo samostojni podjetniki 17-letno tradicijo delovanja (ekstrema pri 4 in 39 let), gospodarske družbe pa 47,7-letno (ekstrema pri 13 in 75 let). $\mathrm{V}$ povprečju imajo samostojni podjetniki manjše število zaposlenih kot gospodarske družbe. Samostojni podjetniki v povprečju zaposlujejo 1 delovodjo, 1,5 gojitelja, 1 sekača, 1 traktorista, 1 šoferja in 1 osebo strokovno - tehničnega kadra. Anketirane gospodarske družbe pa v povprečju zaposlujejo 1,3 delovodje, 4,3 gojitelja, 3,5 sekača, 2 traktorista, 4 šoferje in 1,3 osebe strokovno-tehničnega kadra. Med gospodarskimi družbami jih nekaj več kot polovica $(53,3 \%)$ odkupuje GLS od zasebnih lastnikov gozdov na kamionski cesti, drugo $(46,7 \%)$ pa na panju. Med samostojnimi podjetniki dobra polovica $(59,8 \%)$ odkupuje GLS od zasebnih lastnikov gozdov na panju, petina $(20,2 \%)$ na kamionski cesti, v petini primerov $(20,0 \%)$ pa zasebni lastniki gozdov sami pripeljejo svoje GLS na skladišče samostojnih podjetnikov. 


\subsection{Sedanje stanje gospodarjenja z zasebnimi gozdovi v revirju Vodice}

5.2 Current private forest management situation in the Vodice district

Na podlagi rezultatov ankete smo ugotovili, da je gospodarjenje $\mathrm{z}$ gozdom $\mathrm{v}$ revirju Vodice intenzivno, saj je med anketiranimi zasebnimi lastniki gozdov kar $80,0 \%$ aktivnih. Predvidevamo, da je na tako visoko stopnjo aktivnosti vplival žledolom, ki je v letu 2014 močno poškodoval gozdove v revirju Vodice. Zasebni lastniki gozda, ki niso aktivni $(20,0 \%)$, so kot glavne razloge za neaktivnost navedli neopremljenost za delo v gozdu $(87,8 \%)$, neznanje $(85,4 \%)$, pomanjkanje časa $(73,2 \%)$, pomanjkanje motiva oziroma mišljenje, da od gozda ne bo prihodkov $(61,0 \%)$, nepoznavanje posestnih meja $(56,1 \%)$, solastništvo gozda $(22,0 \%)$, terenske razmere $(12,2 \%)$, neodprtost gozdov $(7,3$ $\%)$ ter nezaupanje izvajalcem gozdarskih del (7,3\%). Zgolj 2,4 \% anketirancev navaja kot razlog, da ne gospodari s svojim gozdom, pomanjkanje informacij. Za delo v gozdu je opremljenih več kot polovica $(57,9 \%)$ aktivnih zasebnih lastnikov gozdov oziroma 46,3\% vseh anketiranih zasebnih lastnikov gozdov. Med aktivnimi zasebnimi lastniki gozdov imajo vsi v lasti motorne žage, 84,2 \% jih ima v lasti za spravilo lesa prilagojen kmetijski traktor, le 5,3 \% pa si lasti gozdarski traktor. Za prevoz GLS imajo v lasti večinoma enoosno prikolico $(73,7 \%)$, gozdarsko prikolico jih ima v lasti le $8,4 \%$, z vitlom pa jih je opremljenih skoraj polovica (46,3\%). Zaradi dobre opremljenosti aktivnih zasebnih lastnikov gozdov jih posledično kar visok delež izvaja različna gozdnogospodarska dela v svojem gozdu (preglednica 1). Najpogosteje zasebni lastniki gozdov sami ali s pomočjo bližnjih družinskih članov opravljajo gojitvena in varstvena dela $(70,1 \%)$, obnovo gozdov $(65,3 \%)$, redno sečnjo $(62,2 \%)$ in sanitarno sečnjo $(48,1 \%)$ ter spravilo lesa $(44,4 \%)$. Majhnemu deležu aktivnih lastnikov gozdov so v pomoč pri opravljanju del tudi sorodniki in/ali sosedje ter prijatelji. Ponudnike gozdarskih storitev pa aktivni zasebni lastniki

Preglednica 1: Način opravljanja del v gozdu pri aktivnih zasebnih lastnikih gozda gozdov najpogosteje najamejo za gradnjo gozdnih vlak $(58,3 \%)$ in prevoz GLS (55,1\%), sledijo opravljanje sanitarnih sečenj $(28,4 \%)$, spravilo lesa $(17,3 \%)$ ter opravljanje rednih sečenj $(15,3 \%)$.

Spoznanje, da zasebni lastniki gozdov opravljajo v svojih gozdovih tako redno kot tudi sanitarno sečnjo, nas ni presenetilo, saj so $\mathrm{v}$ revirju Vodice gozdovi od leta 2014 pogosto izpostavljeni naravnim ujmam (žledolom, podlubniki, vetrolom). Na podlagi ugotovitev sklepamo, da bodo dobro opremljeni zasebni lastniki gozdov večinoma opravljali delo v gozdu sami ali s pomočjo družinskih članov oziroma bodo v prihodnosti najverjetneje le izjemoma poslovno sodelovali s ponudniki gozdarskih storitev. Pri tej skupini zasebnih lastnikov gozdov lahko pričakujemo poslovno sodelovanje s ponudniki gozdarskih storitev zgolj pri opravljanju del, za katera sami niso usposobljeni (sanitarna sečnja in gradnja gozdnih vlak) oziroma za izvedbo nimajo opreme (spravilo lesa in prevoz lesa). Nasprotno pa obstaja večja verjetnost za poslovno sodelovanje s ponudniki gozdarskih storitev v skupini zasebnih lastnikov gozdov, ki so neaktivni in gozdnogospodarskih del v svojih gozdovih ne opravljajo, kar nakazujejo tudi raziskave v tujini (Andersson in Keskitalo, 2019; Andersson in sod., 2020).

\subsection{Pripravljenost zasebnih lastnikov gozdov in ponudnikov gozdarskih storitev za poslovno sodelovanje $\mathrm{v}$ obliki zakupa in upravljanja gozdov}

5.3 Readiness of PFOs and forest service providers for business cooperation through forest leasing and forest management

Za uresničitev ideje o poslovnem sodelovanju med zasebnimi lastniki gozdov in ponudniki gozdarskih storitev v okviru predlaganih poslovnih modelov (zakup in upravljanje gozda) je pomembna obojestranska pripravljenost za tovrstno sodelovanje, zato smo z anketo želeli ugotoviti: a) ali so zasebni lastniki gozdov v preteklih desetih letih že sodelovali s ponudniki gozdarskih stori-

Table 1: Manner of carrying out works in the forest by active PFOs

\begin{tabular}{|l|c|c|c|c|c|}
\hline \multirow{2}{*}{ Vrsta del } & \multicolumn{5}{c|}{ Način opravljanja del (\%) } \\
\cline { 2 - 6 } & Lastnik sam & $\begin{array}{c}\text { Bližnji družinski } \\
\text { člani }\end{array}$ & Sorodniki & Sosedje in prijatelji & $\begin{array}{c}\text { Gozdarsko } \\
\text { podjetje }\end{array}$ \\
\hline Obnova gozda & 65,3 & 45,3 & 9,3 & 4,0 & 2,7 \\
\hline Gojitvena in varstvena dela & 70,1 & 37,7 & 3,9 & 5,2 & 3,9 \\
\hline Redna sečnja & 62,2 & 32,4 & 13,5 & 14,4 & 15,3 \\
\hline Sanitarna sečnja & 48,1 & 27,2 & 17,9 & 14,8 & 28,4 \\
\hline Spravilo lesa & 44,4 & 28,4 & 15,4 & 15,4 & 17,3 \\
\hline Prevoz GLS & 27,6 & 22,4 & 9,6 & 14,7 & 55,1 \\
\hline Gradnja gozdnih vlak & 22,9 & 8,3 & 0,0 & 16,7 & 58,3 \\
\hline
\end{tabular}


tev; b) kakšna je obojestranska stopnja pripravljenosti za poslovno sodelovanje; c) kako primerni se zasebnim lastnikom gozdov in ponudnikom gozdarskih storitev zdijo predlagani pogoji pogodbe o zakupu gozda ter pogodbe o upravljanju; d) ali so zasebni lastniki gozdov pripravljeni za povezovanja v organizacijske oblike na lokalnem nivoju in nadaljnje poslovno sodelovanje s ponudniki gozdarskih storitev oziroma ali so jih le ti pripravljeni pred poslovnim sodelovanjem povezovati.

\subsubsection{Pripravljenost zasebnih lastnikov gozdov za} poslovno sodelovanje s ponudniki gozdarskih storitev v obliki zakupa in upravljanja gozdov

5.3.1 Readiness of PFOs for business cooperation with forest service providers through forest leasing and forest management

Na podlagi rezultatov ankete smo ugotovili, da je v desetletnem obdobju (2007-2017) v revirju Vodice poslovno sodelovala s ponudniki gozdarskih storitev več kot polovica $(54,6 \%)$ zasebnih lastnikov gozdov, ki so večinoma najemali od ponudnikov gozdarskih storitev sečnjo in spravilo oziroma prevoz GLS. Kljub pretežno obsežnemu preteklemu sodelovanju pa je imelo le majhen delež teh zasebnih lastnikov gozdov $(6,9 \%)$ s ponudniki gozdarskih storitev sklenjene pogodbe, ki pa so bile kratkoročne na podlagi izdanih odločb ZGS. Nihče od anketiranih zasebnih lastnikov gozdov ni imel s ponudniki gozdarskih storitev sklenjene dolgoročne pogodbe o zakupu ali upravljanja gozdov. Slednje dejstvo potrjuje že Winkler (1998), ki ugotavlja, da se zakupne pogodbe v Sloveniji sklepajo le izjemoma, le te pa so izrazito kratkoročne (eno- ali dvoletne).

Nadalje nas je zanimalo, koliko zasebnih lastni-

Preglednica 2: Pripravljenost zasebnih lastnikov gozdov za poslovno sodelovanje s ponudniki gozdarskih storitev $\mathrm{v}$ obliki zakupa in upravljanja gozdov nje s ponudniki gozdarskih storitev, kar pripisujemo visoki stopnji aktivnosti zasebnih lastnikov gozdov pri gospodarjenju ter njihovi dobri opremljenosti in usposobljenosti za delo v gozdu. Nasprotno pa lahko drugo polovico zasebnih lastnikov gozdov štejemo kot potencialne poslovne partnerje oziroma kot primerne zasebne lastnike gozdov za poslovno sodelovanje $\mathrm{v}$ poslovnih modelih, saj obstaja velika verjetnost, da bodo pripravljeni za poslovno sodelovanje s ponudniki gozdarskih storitev, če jim bodo pogodbeni pogoji zanimivi oziroma sprejemljivi.

Da bi izvedeli, kakšna je dejanska stopnja pripravljenosti za poslovno sodelovanje $\mathrm{v}$ predlaganih poslovnih modelih (zakup in upravljanje gozdov), smo zasebne lastnike gozdov prosili, naj izrazijo svojo stopnjo pripravljenosti za poslovno sodelovanje v obeh predlaganih poslovnih modelih s pomočjo petstopenjske Likertove lestvice (1 - zelo nepripravljen in 5 - zelo pripravljen). $\mathrm{Na}$ podlagi ocen smo izračunali povprečno vrednost njihove pripravljenosti za poslovno sodelovanje za oba predlagana poslovna modela. Zasebni lastniki gozdov so v povprečju izkazali nizko stopnjo pripravljenosti sodelovanja za oba predlagana poslovna modela, saj so tako oddajo gozda v zakup kot v upravljanje v povprečju ocenili s povprečno oceno 2,9 . Na podlagi njihovih odgovorov smo z združevanjem ocen ${ }^{1}$ identificirali delež zasebnih lastnikov gozdov, ki so pripravljeni/nepripravljeni/neodločeni za poslovno sodelovanje znotraj ponujenih poslovnih modelov (preglednica 2).

Kot je razvidno iz preglednice 2 , je četrtina zasebnih lastnikov gozdov pripravljena za oddajo gozda v zakup ali v upravljanje (26,8 \% za oba poslovna modela). Kljub na videz majhnemu deležu zasebnih lastnikov

Table 2: Readiness of PFOs for business cooperation with forest service providers through forest leasing and forest management

\begin{tabular}{|l|c|c|c|}
\hline \multicolumn{1}{|c|}{ Model poslovnega sodelovanja } & Pripravljeni (\%) & Neodločeni (\%) & Nepripravljeni (\%) \\
\hline Zakup gozda & 26,8 & 35,1 & 38,1 \\
\hline Upravljanje gozda & 26,8 & 37,4 & 35,8 \\
\hline
\end{tabular}

kov gozdov je dejansko pripravljenih za dolgoročno poslovno sodelovanje, torej za sklepanje dolgoročnih pogodb s ponudniki gozdarskih storitev. Ugotovili smo, da bi petina zasebnih lastnikov gozdov $(20,5 \%)$ gospodarjenje z gozdom oddala ponudnikom gozdarskih storitev, s katerimi so $\mathrm{v}$ preteklosti že poslovno sodelovali, 37,5 \% zasebnih lastnikov je neopredeljenih, 49,1\% pa si takega načina poslovnega sodelovanja s ponudniki gozdarskih storitev ne želi. Iz rezultatov lahko sklepamo, da skoraj polovica zasebnih lastnikov gozdov trenutno ni pripravljena za poslovno sodelova- gozdov, ki so pripravljeni za poslovno sodelovanje znotraj predlaganih poslovnih modelov, so rezultati spodbudnejši v primerjavi s tujino (Kurttila in sod., 2016). Kurttila in sod. (2016) so ugotovili, da je v dveh finskih regijah $(\mathrm{n}=2.575)$ pripravljenih oddati svoj gozd $\mathrm{v}$ zakup le 5,0 \% anketiranih zasebnih lastnikov gozdov,

1 Deleže pripravljenih/nepripravljenih in neodločenih zasebnih lastnikov gozdov za poslovno sodelovanje $s$ ponudniki gozdarskihstoritev smo določilizzdruževanjem ocen, in sicer pripravljen (zelo pripravljen + pripravljen), nepripravljen (zelo nepripravljen + nepripravljen) ter neodločen (niti pripravljen niti nepripravljen). 
neodločenih je 12,0 \%, 4,0 \% jih ni odgovorilo, 79,0 \% lastnikov gozdov pa ni pripravljenih. Pri tem poudarjajo, da čeprav je delež pripravljenih zasebnih lastnikov gozdov zelo majhen, sestavljajo skupaj z deležem neodločenih zasebnih lastnikov gozdov kritično množico potencialnih zakupodajalcev, ki imajo v lasti 45.000 gozdnih posesti. Podobna situacija je pri nas, kjer je bil delež neodločenih zasebnih lastnikov gozda za oddajo gozda v zakup in upravljanje dokaj velik $(35,1 \% \mathrm{v}$ primeru zakupa in 37,4 \% v primeru upravljanja), kar pomeni, da kritična množica potencialnih zasebnih lastnikov gozdov, ki so pripravljeni za poslovno sodelovanje s ponudniki gozdarskih storitev, obstaja.

Nizka stopnja pripravljenosti zasebnih lastnikov gozdov za poslovno sodelovanje znotraj ponujenih poslovnih modelov je kljub dobrim izkušnjam s ponudniki gozdarskih storitev lahko tudi posledica nepovezanosti zasebnih lastnikov gozdov $\mathrm{v}$ organizacijske oblike povezovanja na lokalnem nivoju (npr: društva lastnikov gozdov, strojni krožki ali zadruge itd.). Med anketiranimi zasebnimi lastniki je 99,5 \% nepovezanih. Kljub temu, da pretekle raziskave (Pezdevšek Malovrh in sod., 2010a; Kumer in Potočnik Slavič, 2016; Kumer, 2017) kažejo, da se pripravljenost zasebnih lastnikov gozdov za povezovanje iz leta v leto izboljšuje, pa je stanje v revirju Vodice še vedno slabo. V raziskavi Pezdevšek Malovrh in sod. (2010a) je bilo ugotovljeno, da kažejo nižjo stopnjo pripravljenosti za povezovanje zasebni lastniki gozdov manjših gozdnih posesti, kar je

Preglednica 3: Pripravljenost ponudnikov gozdarskih storitev za poslovno sodelovanje z zasebnimi lastniki gozdov v obliki zakupa in upravljanja gozdov
5.3.2 Pripravljenost ponudnikov gozdarskih storitev za poslovno sodelovanje z zasebnimi lastniki gozdov v obliki zakupa in upravljanja gozdov

5.3.2 Readiness of forest service providers for business cooperation through PFOs through forest leasing and forest management

Za uspešno vzpostavitev poslovnih modelov je pomembno, da so za tovrstno sodelovanje pripravljeni ne le zasebni lastniki gozdov, temveč tudi ponudniki gozdarskih storitev. Ponudnike gozdarskih storitev smo najprej prosili, naj se opredelijo, ali so pripravljeni za poslovno sodelovanje $\mathrm{z}$ zasebnimi lastniki gozdov ter da ocenijo svojo pripravljenost za poslovno sodelovanje v okviru obeh predlaganih poslovnih modelov s pomočjo petstopenjske Likertove lestvice (1 - zelo nepripravljen in 5 - zelo pripravljen). Na podlagi ocene smo za vsak poslovni model izračunali povprečno vrednost.

Ponudniki gozdarskih storitev so v povprečju izkazali veliko stopnjo pripravljenosti za poslovno sodelovanje z zasebnimi lastniki gozdov za oba predlagana poslovna modela, saj so tako oddajo gozda v zakup (povprečna ocena $=4,2$ ) kot $\mathrm{v}$ upravljanje gozda (povprečna ocena $=4,3$ ) v povprečju ocenili $\mathrm{z}$ visoko povprečno oceno. Na podlagi njihovih odgovorov smo z združevanjem ocen ${ }^{2}$ identificirali delež ponudnikov gozdarskih storitev, ki so pripravljeni/nepripravljeni/ neodločeni za poslovno sodelovanje v obliki zakupa in upravljanja gozdov (preglednica 3).

Kot je razvidno iz preglednice 3 , sta za poslovni

Table 3: Readiness of forest service providers for business cooperation with PFOs through forest leasing and forest management

\begin{tabular}{|l|c|c|c|}
\hline \multicolumn{1}{|c|}{ Model poslovnega sodelovanja } & Pripravljeni (\%) & Neodločeni (\%) & Nepripravljeni (\%) \\
\hline Zakup gozda & 64,3 & 14,3 & 21,4 \\
\hline Upravljanje gozda & 71,5 & 7,1 & 21,4 \\
\hline
\end{tabular}

lahko tudi razlog za nizko stopnjo povezanosti lastnikov v revirju Vodice, saj v revirju prevladujejo zasebni lastniki gozdov, ki imajo v lasti manjše gozdne posesti.

$\mathrm{S}$ ciljem, da bi zasebnim lastnikom gozdov v prvi vrsti približali povezovanje v organizacijske oblike na lokalnem nivoju in nato poslovno sodelovanje s ponudniki gozdarskih storitev, smo zasebne lastnike gozdov spraševali po njihovi stopnji pripravljenosti za tovrstno povezovanje in nadaljnje poslovno sodelovanje, pri čemer bi bili ponudniki gozdarskih storitev tisti, ki bi jih povezovali. Ugotovili smo, da je 40,0 \% zasebnih lastnikov gozdov pripravljenih za povezovanje v organizacijske oblike na lokalnem nivoju in nadaljnje poslovno sodelovanje s ponudniki. model 1 »zakup zasebnih gozdov« pripravljeni skoraj dve tretjini vseh ponudnikov gozdarskih storitev, za poslovni model 2 »upravljanje gozdov« pa je pripravljenih skoraj tri četrtine vseh anketiranih ponudnikov gozdarskih storitev. Kljub nekoliko manjšemu deležu ponudnikov gozdarskih storitev, ki so pripravljeni za poslovno sodelovanje $\mathrm{v}$ obliki zakupa in upravljanja, tako kot v tujini (Kurttila in sod., 2016), so rezultati spodbudni, saj jim tovrstno sodelovanje pomeni dolgo-

2 Deleže pripravljenih/nepripravljenih in neodločenih ponudnikov gozdarskih storitev za poslovno sodelovanje $\mathrm{z}$ zasebnimi lastniki gozdov smo določili z združevanjem ocen, in sicer pripravljen (zelo pripravljen + pripravljen), nepripravljen (zelo nepripravljen + nepripravljen) ter neodločen (niti pripravljen niti nepripravljen). 
ročno finančno korist. Zato na podlagi rezultatov sklepamo, da obstaja v primeru medsebojne uskladitve pogodbenih pogojev (glej poglavje 5.4) velika verjetnost za vzpostavitev poslovnega sodelovanja med zasebnimi lastniki gozdov in ponudniki gozdarskih storitev $\mathrm{v}$ revirju Vodice.

$\mathrm{S}$ ciljem, da bi predlagani poslovni primeri v praksi tudi zaživeli, smo ponudnike gozdarskih storitev spraševali tudi o njihovi pripravljenosti, da zasebne lastnike gozdov najprej povežejo na lokalnem nivoju $\mathrm{v}$ organizacijske oblike in potem to sodelovanje nadgradijo s poslovnim sodelovanjem. Ugotovili smo, da je $71,4 \%$ ponudnikov gozdarskih storitev pripravljenih povezati zasebne lastnike gozdov na lokalnem nivoju v organizacijske oblike in s tem ustvariti predpogoj za dolgoročno poslovno sodelovanje.

\subsection{Ocena primernosti pogodbenih pogojev za predlagana poslovna modela}

5.4 Assessment of the eligibility of the contractual terms for the proposed business models

Predlagana poslovna modela sodelovanja (zakup gozda in upravljanje gozda) med zasebnimi lastniki gozdov in ponudniki gozdarskih storitev se sklepata na podlagi dolgoročnih poslovnih pogodb. Od zasebnih lastnikov gozdov in ponudnikov gozdarskih storitev smo želeli izvedeti, ali so predlagani pogodbeni pogoji poslovnega sodelovanja, ki urejajo poslovno razmerje in temeljne obveznosti, opisani v poglavju 3.1 in 3.2, zanje primerni. Njihovo primernost smo ocenjevali na dihotomni lestvici (0 - neprimerno, 1 - primerno).

Na podlagi rezultatov smo ugotovili, da so za večino zasebnih lastnikov gozdov in ponudnikov gozdarskih storitev predlagani pogoji poslovnih modelov primerni (preglednica 4).

Največjemu deležu zasebnih lastnikov gozdov se zdijo primerni pogodbeni pogoji zakupnega razmerja,

Preglednica 4: Delež zasebnih lastnikov gozdov in ponudnikov gozdarskih storitev, ki ocenjujejo posamezne pogoje poslovnih modelov za primerne ki so povezani z ekonomskimi pogoji (stalni letni prihodki, ki se izplačujejo lahko mesečno/polletno ali letno ter variabilni skupni prihodki zakupnega obdobja) ter pogodbeno obdobje, ki sledi desetletnemu obdobju veljavnosti gozdnogospodarskih načrtov. Kot nekoliko manj primerne pogodbene pogoje zakupnega razmerja imajo tiste, ki so povezani z dinamiko opravljanja gozdnogospodarskih del, saj se pri zakupu zasebni lastniki gozdov ne morejo sami odločati, kdaj se bodo dela opravljala. Edini v povprečju neprimerno ocenjeni pogoj zakupne pogodbe, ki jo manj kot polovica lastnikov gozdov ocenjuje kot primerno, je možnost prekinitve poslovnega razmerja, saj je pri zakupu možno to storiti predčasno brez razloga le $v$ zameno za nadomestilo (npr. enoletna zakupnina). Nasprotno pa večina zasebnih lastnikov gozdov ocenjuje možnost prekinitve poslovnega razmerja kot enega izmed najprimernejših pogojev pogodbe o upravljanju gozdov, saj pri upravljanju zasebni lastnik gozda lahko prekine pogodbo predčasno brez razloga kadarkoli brez finančnih posledic. Podoben delež zasebnih lastnikov gozdov pri upravljanju gozdov ocenjuje pogodbeno obdobje kot primerno, saj velja, da se sklepa za večletno neomejeno časovno obdobje $v$ skladu z veljavnim gozdnogospodarskim načrtom. Kot primerno ocenjen pogoj pogodbe o upravljanju se nanaša na dinamiko opravljanja gozdnogospodarskih del, saj se lahko zasebni lastnik gozda sam odloči, kdaj bo dela opravljal v skladu s lastnimi cilji gospodarjenja znotraj gozdnogospodarskih načrtov. Slabše ocenjeni pogoji pogodbe o upravljanju pa so povezani s skupnimi prihodki, saj so odvisni od prodaje GLS, za katero pa je odgovoren upravitelj gozda, sledijo letni prihodki, saj so le-ti neenakomerni oziroma odvisni od prihodkov, povezanih z obsegom gospodarjenja z gozdom. Vsi anketirani ponudniki gozdarskih storitev so kot najprimerneje pogoje zakupne pogodbe ocenili skupne prihodke za pogodbeno obdobje, sledijo pogodbeno obdobje, dinamika opra-

Table 4: Share of PFOs and forest service providers to whom the terms of business models contract appear appropriate

\begin{tabular}{|c|c|c|c|c|}
\hline \multirow{2}{*}{$\begin{array}{l}\text { Pogodbeni pogoji } \\
\text { poslovnega modela }\end{array}$} & \multicolumn{2}{|c|}{ Zakup gozda } & \multicolumn{2}{|c|}{ Upravljanje gozda } \\
\hline & $\begin{array}{c}\text { Delež zasebnih } \\
\text { lastnikov gozdov (\%) }\end{array}$ & \begin{tabular}{|c|} 
Delež ponudnikov \\
gozdarskih storitev (\%)
\end{tabular} & $\begin{array}{c}\text { Delež zasebnih } \\
\text { lastnikov gozdov (\%) }\end{array}$ & \begin{tabular}{|c|} 
Delež ponudnikov \\
gozdarskih storitev (\%)
\end{tabular} \\
\hline Pogodbeno obdobje & 73,6 & 83,0 & 83,1 & 91,7 \\
\hline Odpoved pogodbe & 43,7 & 44,4 & 83,2 & 33,3 \\
\hline $\begin{array}{l}\text { Dinamika izvajanja sečnje in spravila } \\
\text { lesa }\end{array}$ & 50,8 & 75,0 & 87,1 & 66,7 \\
\hline $\begin{array}{l}\text { Dinamika izvajanja gojitvenih in var- } \\
\text { stvenih dela }\end{array}$ & 63,0 & 66,7 & 79,8 & 66,7 \\
\hline Letni prihodki & 87,2 & 60,0 & 56,5 & 66,7 \\
\hline $\begin{array}{l}\text { Skupni prihodki za pogodbeno ob- } \\
\text { dobje }\end{array}$ & 86,8 & 100,0 & 60,6 & 100,0 \\
\hline
\end{tabular}


vljanja gozdnogospodarskih del ter letnimi prihodki. S strani ponudnikov gozdarskih storitev je edini pogoj zakupne pogodbe, ki ga manj kot polovica ponudnikov gozdarskih storitev ima za primernega, povezan z možnostjo prekinitve poslovnega razmerja saj je pri zakupu možno to storiti predčasno brez razloga, seveda pa v zameno za nadomestilo. Prav tako možnost prekinitve poslovnega razmerja pri pogodbi o upravljanju ocenjuje manj kot polovica anketiranih ponudnikov gozdarskih storitev kot primeren pogoj, saj tudi pri upravljanju zasebni lastnik gozda lahko prekine pogodbo brez razloga kadarkoli in sicer brez finančnih posledic. Vsi drugi pogoji pogodbe o upravljanju so se po ocenah ponudnikov gozdarskih storitev izkazali za primerne.

\section{ZAKLJUČKI IN SMERNICE ZA VZPOSTAVITEV POSLOVNEGA SODELOVANJA MED ZASEB- NIMI LASTNIKI GOZDOV IN PONUDNIKI GOZDARSKIH STORITEV V OKVIRU PREDLA- GANIH POSLOVNIH MODELOV}

6 CONCLUSIONS AND GUDELINES FOR THE ESTABLISHEMNT OF BUSINESS COOPERATION BETWEEN PFOS AND FOREST SERVICE PROVIDERS IN THE CONTEXT OF THE PROPOSED BUSINESS MODELS

Ker se gozdna politika povezovanja trenutno usmerja v spodbujanje gospodarskih oblik povezovanja in sodelovanja, pri katerih bi sodelovale zunanje gospodarske družbe, in ker v sedanjem institucionalnem okviru niso jasne interesne povezave med posameznimi deležniki (Šinko, 2012), še posebej, če je cilj gospodarsko (poslovno) sodelovanje, je pomembno, da v prvi vrsti opredelimo deležnike poslovnega sodelovanja in njihove aktivnosti ter preverimo, ali je poslovno sodelovanje med njimi uresničljivo.

Rezultati naše raziskave so nakazali na smiselnost poslovnega sodelovanja med zasebnimi lastniki gozdov in ponudniki gozdarskih storitev v okviru predlaganih poslovnih modelov, saj je pripravljenost za poslovno sodelovanje s strani zasebnih lastnikov gozdov in ponudnikov gozdarskih storitev zadovoljiva. Prav tako je pripravljenost za povezovanje $\mathrm{v}$ organizacijske oblike na lokalnem nivoju s strani zasebnih lastnikov gozdov dobra, pri čemer so se kot deležnik, ki bi jih povezoval, izkazali kar ponudniki gozdarskih storitev sami, saj bi si s tem ustvarili predpogoj za nadaljnje dolgoročno poslovno sodelovanje. S povezovanjem zasebnih lastnikov gozdov pa bi po našem mnenju zadostili predpogojem za kakršnokoli poslovno povezovanje, saj je poslovno sodelovanje ekonomsko bolj upravičeno na večjih zaokroženih gozdnih kompleksih (Górriz-Mifsud, 2019).
Na podlagi rezultatov, ki smo jih pridobili $\mathrm{v}$ raziskavi, je poslovno sodelovanje med zasebnimi lastniki gozdov in ponudniki gozdarskih storitev znotraj predlaganih poslovnih modelov (zakup ali upravljanje gozda (delno) uresničljivo, saj:

- Socio-demografske značilnosti zasebnih lastnikov gozdov nakazujejo, da so zasebni lastniki gozdov v povprečju stari okoli 60 let, visoko izobraženi, nekmetje ki so v polovici primerov delovno aktivni, zato lahko v prihodnosti s strani zasebnih lastnikov gozdov pričakujemo povečanje potrebe po najemanju storitev, povezanih z gospodarjenjem z gozdom pri ponudnikih gozdarskih storitev.

- Stopnja aktivnosti pri gospodarjenju z gozdom je zaradi naravnih ujm v zadnjih letih zelo visoka $(80,0 \%$ zasebnih lastnikov gozdov je opravljalo dela v gozdovih), za delo v gozdu pa je opremljena skoraj polovica vseh zasebnih lastnikov gozdov, ki posledično izvajajo dela sami ali s pomočjo družinskih članov. Slednji bodo v prihodnosti najverjetneje le izjemoma poslovno sodelovali s ponudniki gozdarskih storitev. Poslovno sodelovanje s ponudniki gozdarskih storitev je pri tej skupini zasebnih lastnikov gozdov moč pričakovati le za opravljanje del, za katera sami niso usposobljeni (sanitarna sečnja in gradnja gozdnih vlak) oziroma nimajo opreme (spravilo lesa in prevoz lesa). Nasprotno pa obstaja večja verjetnost za poslovno sodelovanje $s$ ponudniki gozdarskih storitev v skupini zasebnih lastnikov gozdov, ki so neaktivni in ne opravljajo del v svojih gozdovih ali pa so neopremljeni za delo v gozdu oziroma nimajo potrebnega znanja.

- Stopnjo sodelovanja zasebnih lastnikov gozdov s ponudniki gozdarskih storitev $\mathrm{v}$ desetletnem obdobju ocenjujemo kot zadovoljivo (dobra polovica zasebnih lastnikov gozdov je sodelovala s ponudniki gozdarskih storitev), zato lahko pričakujemo da se bo trend sodelovanja nadaljeval, predvsem pri zasebnih lastnikih gozdov, ki so imeli pozitivno izkušnjo s preteklim sodelovanjem. Zasebni lastniki gozdov so $\mathrm{v}$ večini primerov najemali od ponudnikov gozdarskih storitev storitve sečnje in spravila oziroma prevoza GLS, zato lahko pričakujemo, da se bo povpraševanje po teh storitvah tudi v prihodnosti nadaljevalo.

- Delež zasebnih lastnikov gozdov, ki so imeli s ponudniki gozdarskih storitev sklenjene pogodbe, je zelo nizek (malo nad $6 \%$ ) poleg tega pa so bile pogodbe kratkoročne, zgolj na podlagi izdanih odločb ZGS. Slednje lahko pomenijo oviro za poslovno sodelovanje na dolgi rok, saj preteklih izkušenj in primerov dobrih praks poslovnega sodelovanja pri zasebnih lastnikih gozdov ni. 
- Pripravljenost za dolgoročno poslovno sodelovanje je s strani zasebnih lastnikov gozdov nižja v primerjavi s ponudniki gozdarskih storitev. Je pa med zasebnimi lastniki gozdov več kot tretjina takih, ki so neodločeni glede poslovnega sodelovanja. Le-ti sestavljajo kritično množico potencialnih partnerjev za poslovno sodelovanje v prihodnosti, če bi obstajal deležnik, ki bi jim predstavil prednosti in jih motiviral za tovrstno sodelovanje. Razlik v pripravljenosti za poslovno sodelovanje med zakupom in upravljanjem gozdov pri zasebnih lastnikih gozdov ni opaziti. Pri ponudnikih gozdarskih storitev se kažejo majhne razlike - večji delež jih je pripravljenih za poslovni model upravljanja gozdov.

- Predlagani pogoji zakupne pogodbe in pogodbe o upravljanju, ki urejajo poslovno razmerje in temeljne obveznosti pogodbenih strank, so se izkazali za primerne tako za zasebne lastnike gozdov kot tudi za ponudnike gozdarskih storitev. Razlike v njihovih ocenah sicer obstajajo, pri čemer je večjo sprejemljivost pogodbenih pogojev zaznati s strani ponudnikov gozdarskih storitev. Na podlagi njihovih ocen lahko sklepamo, da so ponudniki gozdarskih storitev bolj prilagodljivi pri sklepanju dolgoročnih pogodb, saj so vsi pogodbeni pogoji za njih sprejemljivi.

Za začetek vzpostavitve poslovnega sodelovanja med zasebnimi lastniki gozdov in ponudniki gozdarskih storitev je treba v prvi vrsti poskrbeti za promocijo poslovnega povezovanja in sodelovanja na lokalnem nivoju, kjer bi glede na trenutno zakonodajo pobudo lahko prevzela le Zveza lastnikov gozdov Slovenije ali pa Kmetijsko gozdarska zbornica Slovenije. Nadalje je potrebno vzpostaviti poslovne odnose med potencialnimi poslovnimi partnerji, torej zasebnimi lastniki gozdov in ponudniki gozdarskih storitev. Pri tem je pomembno, da se v poslovni model vključijo zaupanja vredni in zanesljivi ponudniki gozdarskih storitev, ki bodo poskrbeli za korektne odnose, ponudbe z jasnimi ekonomskimi kazalniki ter dela $v$ gozdu opravljali kakovostno. S tem bodo med zasebnimi lastniki gozdov krepili zaupanje v poslovno sodelovanje, medtem ko sami lastnikom gozdov zaupajo, na kar nakazuje njihova visoka stopnja pripravljenosti na poslovno povezovanje. Na uspešnost vzpostavitve poslovnih modelov bi imeli lahko ključno vlogo revirni gozdarji ZGS, ki najbolje poznajo tako gozdove kot tudi zasebne lastnike gozdov, njihovo aktivnost gospodarjenja, njihov socialno-ekonomski status, interese in želje. Če bi bilo slednje zakonsko omogočeno, bi posredovanje informacij revirnih gozdarjev zagotavljalo, da potencialni zakupnik ali upravitelj v množici zasebnih lastni- kov gozdov usmeri svoj interes in pobudo k tistim, ki ne gospodarijo z gozdom in najbrž tudi v prihodnje ne bodo (predvsem zaradi starosti, neodvisnosti od gozda, neopremljenosti, neznanja in »novih tipov zasebnih lastnikov gozdov«).

\section{POVZETEK}

\section{SUMMARY}

Because the forest policy cooperation concept is currently aimed at promoting economic forms of cooperation in which external companies can also participate (Šinko, 2012), and because there are no clear links of interest between individual stakeholders in the current institutional framework (Šinko, 2012), especially if the goal is economic (business) cooperation, it is important to first define the actors of business cooperation and their activities and to examine whether business cooperation between them is feasible.

Our research has shown the feasibility of business cooperation between private forest owners and forest service providers within the proposed business models (forest lease and forest management), as the willingness to engage in business cooperation is satisfactory on the part of private forest owners and above average on the part of forest service providers. The willingness to cooperate in organizational forms at the local level on the part of private forest owners is also good, with forest service providers themselves proving to be the stakeholder in connecting private forest owners, as this creates the conditions for long-term business cooperation. However, by connecting private forest owners, they create the conditions for business cooperation, as business cooperation is only economically justified in larger and well-rounded forest complexes. Based on the research results, business cooperation between private forest owners and forest service providers is feasible under the proposed business models, as the level of cooperation of private forest owners with forest service providers over a 10-year period was satisfactory, and the proposed terms and conditions governing business relationship and the basic contract obligations of the contracting parties have proven to be appropriate for both business partners.

In order to initiate business cooperation between private forest owners and forest service providers, it is first necessary to promote business cooperation at the local level, where the initiative could come from the Slovenian Forest Owners Association or the Chamber of Agriculture and Forestry of Slovenia. Furthermore, it is necessary to establish connections between potential business partners, i.e. private forest owners and forest service providers. It is important 
to include trustworthy and reliable forest service providers in the business model, who take care of proper relations, make offers with clear economic indicators and perform quality work in the forest. This will build trust between private forest owners for business cooperation. The public forestry service and its district foresters also play an important role in the success of establishing business models, as they know the private forest owners and their socio-economic status, which would allow a potential lessee or manager to direct his interest and initiative towards the forest owners who do not manage the forest and are unlikely to manage it in the future (mainly due to independence from the forest, new types of owners).

\section{ZAHVALA}

\section{ACKNOWLEDGEMENTS}

Za dragoceno pomoč pri raziskavi se zahvaljujejo zasebnim lastnikov gozda na območju revirja Vodice in vsem ponudnikom gozdarskih storitev. Pregled možnih oblik poslovnega sodelovanja med zasebnimi lastniki gozdov in ponudniki gozdarskih storitev podajamo kot rezultat v okviru projekta CRP (V4-2013): »Izhodišča za izboljšanje gospodarjenja z zasebnimi gozdovi v podporo večji mobilizaciji lesa«, delovni sklop 4: »Poslovni modeli med zasebnimi lastniki gozdov in drugimi deležniki«. Zahvaljujemo se Ministrstvu za kmetijstvo, gozdarstvo in prehrano ter Javni agenciji za raziskovalno dejavnost Republike Slovenije za financiranje projekta.

\section{VIRI}

\section{REFERENCES}

Andersson E., Keskitalo E.C.H. 2019. Service logics and strategies of Swedish forestry in the structural shifts of forest ownership: challenging the "old" and shaping the "new". Scandinavian Journal of Forest Research, 34, 6: 508-520.

Andersson E., Keskitalo E.C.H., Westin K. 2020. Managing place and distance: restructuring sales and work relations to meet urbanisation-related challenges in Swedish forestry. Forest Policy and Economics, 118, 102267.

Baza podatkov ZGS za revir Vodice. 2020. Ljubljana, Zavod za gozdove Slovenije (izpis iz baze podatkov, 13. okt. 2020).

Beach R.H., Pattanayak S.K., Yang J.C., Murray B.C., Abt R.C. 2005. Econometric studiesof non-industrial private forest management: a review and synthesis. Forest Policy and Economics, 7, 3: 261-281.

Breznikar A., Krajnc N., Ščap Š., Cojzer M. 2017. Priročnik za krepitev gozdarskega svetovanja na področju mobilizacije gozdnih lesnih virov v Sloveniji. Ljubljana, Zavod za gozdove Slovenije, Gozdarski inštitut Slovenije: 85 str.

Côté M.A., Généreux-Tremblay A., Gilbert D., Gélinas N. 2017. Comparing the profiles, objectives and behaviours of new and longstanding non-industrial private forest owners in Quebec, Canada. Forest Policy and Economics, 78: 116-121.

Calculator. 2017. Sample size calculator. Sample Size Calculator (13. 5. 2017)
Černač G., Pezdevšek Malovrh Š. 2020. Analiza uspešnosti prodaje gozdnih lesnih sortimentov v gozdarski zadrugi lastnikov gozdov Pohorje - Kozjak. Zbornik gozdarstva in lesarstva, 122: 1-17.

Erlandsson E. 2013. The impact of industrial context on procurement, management and development of harvesting services: a comparison of two Swedish forest owners associations. Forests, 4, 4: 1171-1198. DOI.org/10.3390/f4041171

Fabra-Crespo M., Rojas-Briales E. 2015. Comparative analysis on the communication strategies of the forest owners' associations in Europe. Forest Policy and Economics, 50: 20-30.

Field A. 2018. Discovering statistics using IBM SPSS Statistics. $5^{\text {th }}$ ed. London, Sage publications: 816 str.

Glück P., Avdibegović M., Čabaravdić A., Nonić D., Petrović N. in sod. 2010. The preconditions for the formation of private forest owners' interest associations in the western Balkan region. Forest Policy and Economics, 12, 4: 250-263.

Górriz-Mifsud E., Olza Donazar L., Montero Eseverri E., Marini Govigli V. 2019. The challenges of coordinating forest owners for joint management. Forest Policy and Economics, 99: 100-109.

Hansmann R., Kilchling P., Seeland K. 2016. The effects of regional forest owner organizations on forest management in the Swiss canton of Lucerne. Small-scale Forestry, 15, 2: 159-177.

Hrib M., Slezová H., Jarkovská M. 2018. To join small-scale forest owners' associations or not? Motivations and opinions of smallscale forest owners in three selected regions of the Czech Republic. Small-scale Forestry, 17: 147-164.

Iveta N. 2017. Ocena pripravljenosti zasebnih lastnikov gozdov za poslovno sodelovanje pri gospodarjenju z gozdom na primeru revirja Vodice: magistrsko delo. (Univerza v Ljubljani, Biotehniška fakulteta, Oddelek za gozdarstvo in obnovljive gozdne vire). Ljubljana, samozaložba: 137 str.

Karppinen H. 2012. New forest owners and owners-to-be: apples and oranges? Small-scale Forestry, 11, 1:15-26.

Krajčič D., Mori J. 2006. Profesionalizacija dela društev lastnikov gozdov Gozdarski vestnik, 64, 3: 168-173.

Kronholm T. 2016. How are Swedish forest owners' associations adapting to the needs of current and future members and their organizations? Small-scale Forestry, 15, 4: 413-432.

Kumer P. 2017. Vpliv družbenogeografskih dejavnikov na gospodarjenje z majhnimi zasebnimi gozdnimi posestmi: doktorska disertacija. (Univerza v Ljubljani, Filozofska fakulteta). Ljubljana, samozaložba: 157 str.

Kumer P., Potočnik Slavič I. 2016. Heterogeneous small-scale forest ownership: complexity of management and conflicts of interest. Revue Belge de Geographie, 4: 21 str. DOI.org/10.4000/belgeo.19354

Kurttila M., Hujala T., Hänninen H., Kumela H. 2016. Family forest owners' opinion on potential forest leasing service in Finland. V: Forest ownership changes in Europe: trends, issues and needs for action. Final conference of the COST Action FP1201 FACESMAP, Vienna, Austria, 7-9 September 2016: book of abstracts. Weiss G., Dobšinska Z., Feliciano D., Hujala T., Lawrence A., Lidestav G., Sarvašova Z., Živojinović I. (ur.). Vienna, European Forest Institute: 83-85.

Laakkonen A., Hujala T., Pykäläinen J. 2019. Integrating intangible resources enables creating new types of forest services - developing forest leasing value network in Finland. Forest Policy and Economics, 99: 157-168.

Leban V. 2014. Analiza učinkovitosti delovanja društev lastnikov gozdov v Sloveniji in Nemčiji: magistrsko delo. (Univerza v Ljubljani, Biotehniška fakulteta, Oddelek za gozdarstvo in obnovljive gozdne vire). Ljubljana, samozaložba: 129 str.

Matilainen A., Koch M., Živojinović I., Lähdesmäki M., Lidestav G. in sod. 2019. Perceptions of ownership among new forest owners - a qualitative study in European context. Forest Policy and Economics, 99: 43-51. 
Medved M. 2000. Gozdnogospodarske posledice posestne sestave slovenskih zasebnih gozdov: doktorska disertacija. (Univerza v Ljubljani, Biotehniška fakulteta, Oddelek za gozdarstvo in obnovljive gozdne vire). Ljubljana, samozaložba: 228 str.

Mizaraite D., Mizaras S. 2014. Cooperation of private forest owners as a factor for sustainable forest management. V: Future directions of small-scale and community-based forestry. Fukuoka, Japan, IUFRO 3.08\&6.08 Conference. Kawasaki A. (ur.). Fukuoka: 150-160.

Mori J. 2012. Delo Zveze lastnikov gozdov Slovenije in lokalnih društev lastnikov gozdov v zadnjih petih letih. V: Povezovanje lastnikov gozdov in skupno gospodarjenje: zbornik razširjenih izvlečkov: XXIX. gozdarski študijski dnevi. Marenče J. (ur.). Ljubljana, Biotehniška fakulteta, Oddelek za gozdarstvo in obnovljive gozdne vire: 23-25.

Mori J., Kotnik I., Lesnik T. 2006. Možnost sodelovanja Zavoda za gozdove Slovenije, Kmetijsko gozdarske zbornice Slovenije in Zveze lastnikov gozdov Slovenije za razvoj povezovanja lastnikov gozdov. Gozdarski vestnik, 64, 9: 476-502.

Obligacijski zakonik. 2007. Ur. l. RS, št. 97/2007.

Operativni program za izvajanje Nacionalnega gozdnega programa 2017-2021. 2017 http://www.mkgp.gov.si/fileadmin/mkgp. gov.si/pageuploads/podrocja/Gozdarstvo/17_08_21_OPNGP_ koncna.pdf (28. 9. 2020).

Pezdevšek Malovrh Š. 2010. Vpliv institucij in oblik povezovanja lastnikov gozdov na gospodarjenje $\mathrm{z}$ zasebnimi gozdovi: doktorska disertacija. (Univerza v Ljubljani, Biotehniška fakulteta). Ljubljana, samozaložba: 224 str.

Pezdevšek Malovrh Š., Zadnik Stirn L., Krč J. 2010a. Influence of property and ownership conditions on willingness to cooperate. Šumarski list, 134, 3-4: 139-149.

Pezdevšek Malovrh Š., Hodges D.G., Marić B., Avdibegović M. 2011. Private forest owners expectations of interest associations: comparative analysis between Slovenia and Bosnia-Herzegovina. Šumarski list, 135: 1-10.

Pezdevšek Malovrh Š., Nonić D., Glavonjić P., Nedeljković J., Avdibegović M. in sod. 2015. Private forest owner typologies in Slovenia and Serbia: targeting private forest owner groups for policy implementation. Small-scale Forestry, 14, 4: 423-440.

Pezdevšek Malovrh Š., Laktić T. 2017. Poslovno povezovanje lastnikov gozdov na primeru Društva lastnikov gozdov Pohorje-Kozjak. Acta Silvae et Ligni, 113: 1-13.

Pezdevšek Malovrh Š., Kumer P., Glavonjić P., Nonić D., Nedeljković J., Kisin B., Avdibegović M. 2017. Different organizational models of private forest owners as a possibility to increase wood mobilization in Slovenia and Serbia. Croatian Journal of Forest Engineering, 38, 1: 127-140.

Poje A., Pezdevšek Malovrh Š., Krč J. 2016. Factors affecting harvesting intensity in small-scale private forests in Slovenia. Smallscale Forestry, 15, 1: 73-91.
Põllumäe P., Korjus H., Kaimre P., Vahter T. 2014. Motives and incentives for joining forest owner associations in Estonia. Small-scale Forestry, 13, 1: 19-33.

Poročilo o izvajanju Nacionalnega gozdnega programa do 2014. 2016. Ljubljana, Ministrstvo za kmetijstvo, gozdarstvo in prehrano: 97 str.

Poročilo Zavoda za gozdove Slovenije o gozdovih za leto 2018. 2019. Ljubljana, Zavod za gozdove Slovenije. http://www.zgs. si/fileadmin/zgs/main/img/PDF/LETNA_POROCILA/2018_ Porocilo_o_gozdovih.pdf (20. 2. 2020).

Resolucija o nacionalnem gozdnem programu (ReNGP). 2007. Ur. 1. RS, št. 111/2007.

Šálka J., Dobšinská Z., Hricová Z. 2016. Factors of political power - the example of forest owners' associations in Slovakia. Forest Policy and Economics, 68: 88-98.

Šinko M. 2012. Institucionalno in strukturno ozadje povezovanja gozdnih proizvajalcev. V: Povezovanje lastnikov gozdov in skupno gospodarjenje: zbornik razširjenih izvlečkov: XXIX. gozdarski študijski dnevi. Marenče J. (ur.). Ljubljana, Biotehniška fakulteta, Oddelek za gozdarstvo in obnovljive gozdne vire: 11-13.

Umaerus P., Högvall Nordin M., Lidestav G. 2019. Do female forest owners think and act "greener"? Forest Policy and Economics, 99: 52-58.

Weiss G., Dragoi M., Jarsky V., Mizaraite D., Sarvašova Z., Schiberna E., Gudurić I. 2012a. Success cases and good practices in forest owners' organizations in Eastern European countries. Food and Agriculture Organization of the United Nations, Rome: 35 str.

Weiss G., Gudurić I., Wolfslehner B. 2012b. Review of forest owners' organizations in selected Eastern European countries. V: Forest policy an institutional working paper. Qiang M. (ur.) Food and Agriculture Organization of the United Nations, Rome: 57 str.

Weiss G., Lawrence A., Hujala T., Lidestav G., Nichiforel L. in sod. 2019a. Forest ownership changes in Europe: state of knowledge and conceptual foundations. Forest Policy and Economics, 99: 9-20.

Weiss G., Lawrence A., Lidestav G., Feliciano D., Hujala T. in sod. 2019b. Research trends: forest ownership in multiple perspectives. Forest Policy and Economics, 99: 1-8.

Winkler I. 1998. Zakup gozdov in koncesija za gospodarsko izkoriščanje državnih gozdov v Sloveniji. Zbornik gozdarstva in lesarstva, 57: 207-233.

Zakon o kmetijskih zemljiščih. 2011. Ur. l. RS, št. 71/2011. 